\title{
UNDERSTANDING THE FACTORS THAT SHAPED THE NEGATIVE IMAGE OF TURKS IN EUROPE AND ITS EFFECTS ON TURKEY'S EU MEMBERSHIP
}

\section{TÜRKLERIN AVRUPA'DAKİ NEGATIFF IMMAJINI ŞEKILLENDİREN FAKTÖRLERİ VE BU FAKTÖRLERIN TÜRKIYYE'NIN AB ÜYELİĞINE ETKISIINI ANLAMAK}

\author{
Serpil ÖZTÜRK \\ Sakarya University, Institute of Social Sciences \\ srplozturk@hotmail.com
}

\begin{abstract}
The prospect of Turkey's entry into EU has triggered intense identity-based discussions. The evaluation of Turkey's possible membership within the context of its distinctive character has generated strong antagonism in European countries especially in those who share large Turkish populations. This antagonism is rooted in the negative image of Turks, which has shaped the European's opinions about Turks. There are intertwined factors that played essential role: The historical image of the Turks together with the widespread belief regarding Turkish migrant's integration 'failures' reflects the negative image of the Turks in the mind of Europeans. The common attitudes of the Turkish communities towards some values that European identity based on such as gender equality have shaped the Europeans opinions which is increasingly concerned with the issue. Turkish community's approach thus stimulates the fears of Europeans regarding Turkey's entry, which in turn decrease in support for Turkey.
\end{abstract}

Key Words: Perceptions, European Union, Turkey

\section{Özet}

Türkiye'nin Avrupa Birliği’ne giriş süreci kimlik temelli yoğun tartışmalar ortaya çıkarmıştır. Türkiye'nin muhtemel üyeliği'nin 'farklı' karakteri bağlamında değerlendirilmesi özellikle Türk nüfusun yoğun olduğu Avrupa Birliği ülkelerinde güçlü bir muhalefet doğurmuştur. Türkiye'nin üyeliğine olan bu muhalefet, Avrupalıların görüşlerini şekillendiren olumsuz Türk imajında temellenmektedir. Birbirleri ile bağlantılı olan bir kaç faktör bu konuda önemli rol oynamıştır: Türklerin tarihi imajı ile birlikte Türk göçmenlerin entegrasyon 'başarısızlıkları'na olan yaygın inanç Türklerin Avrupalıların akıllarında oluşmuş olan negatif imajını yansıtmaktadır. Türk toplumunun Avrupa'nın üzerine temellendiği bazı değerlere karşı olan yaklaşımı Avrupalıların Türkler hakkındaki görüşlerini önemli ölçüde şekillendirmektedir. Türk toplumunun bu yaklaşımı Türkiye'nin AB'ye üyeliği konusundaki korkuları arttırmakta, bunun sonucunda da Türkiye'ye olan destek düşük seviyede kalmaktadır.

Anahtar Sözcükler: Alg1, Avrupa Birliği, Türkiye 


\section{Introduction}

'It is harder to crack a prejudice than an atom'

Albert Einstein

During the recent years and, especially after 2005 when enlargement negotiations started between Turkey and the EU, the debate on Turkish accession to the EU has gained much attention on the basis of identity, value system, religious orientations, and history. The vast majority of European citizens, as well as various political parties, especially on the right wing, have been rejecting the idea of accepting Turkey into EU on the grounds that Turkey differs a lot from the rest of the Europe. However, when the Ankara Agreement was signed between Turkey and the European Economic Community (EEC), Walter Hallstein, the President of the EEC Commission, stated that 'Turkey is part of Europe' (Tekin, 2005: 287). As Walter Hallstein declared bluntly over 4 decades ago, Turkey was recognized by the EU as a European country, and, Turkey's 'Europeanness' was not questioned due to the existing international environment. In the cold war era, Turkey's strategic importance was crucial both for the European security and for the West in general. Under these circumstances Turkey was recognized as a part of Europe. This situation continued until the collapse of communism. 'When the defence of European civilization (against communism) was at stake', as the former Turkey's president Süleyman Demirel remarked, 'they didn’t say that we were Turks and Muslims' (Müftüler-Bac, 2000: 23).

This negative attitude towards Turkey's EU membership and the Turks in general, was enhanced also by two incidents. With the breakdown of communism, cultural and religious norms and values in general came to the fore as a distinctive element among civilizations. As a result, these elements led the countries to construct new boundaries to separate them from the outsiders, or 'others'. Additionally, the rising religious fundamentalism among Muslims made this change somehow inevitable for the European countries, especially the ones who had Muslim minorities as settlers. This growing international concern with the rise of Islamic fundamentalism across a broad geographic region encompassing Central Asia, the Middle East and North Africa, began to influence perceptions of Turkey (Verney, 2007: 216). This paper aims to examine the factors that shaped the negative image that Europeans have for the Turks. The first section deals with the Turkish identity, presents how it was shaped as it is today, over time and explains why it is different from the identity of many Europeans. After establishing the basic knowledge on what is the Turkish identity I attempt, in the second section, to unveil the factors that shape the negative image of the Turks. Finally the paper concludes by presenting a discussion on the impact of this negative image on Turkey's membership in EU.

\section{Historical Overview of Turkish Identity}

In parallel to Europe's identity reformulation, Turkey is going through its own identity crisis that began in the nineteenth century and still lingers (Müftüler-Bac, 2000:31). Turkish identity has been transformed within the extent of modernization, generally understood as westernization (Inac, 2004: 33), which constitutes the core element of political orientations of Turkey during the last two-hundred year. This process of westernization can be divided into two major periods. The first began with the Ottoman Modernization, also known 
as Tanzimat, and the second is the Kemalist Modernization that was emerged with the collapse of the Ottoman Empire.

\subsection{The Ottoman Modernization}

The construction of the Turkish identity dates back to the Ottoman modernization(Tanzimat) that aimed in strengthening the Ottoman identity through granting equality to the millets under the Ottoman reign. The aim was to encourage 'Ottomanism' among the ethnically diverse groups of the Empire. However, the attempts for re-integrating diverse nationalities and especially the non- Muslims, had a far-reaching effect. Nationalist movements (started with the Greek Revolution) gained momentum, which eventually included even Muslim citizens. Yet, even though the Tanzimat period produced a nationalist awakening of a Turkish identity with the contribution of free thinkers like Mustafa Kemal Atatürk, the emergence of Turkish identity was the last phase among nationalist movements. It is important to note that the multi-ethnic, multi-religious Ottomans, also known in the West as the Turkish Empire, had disowned this ethnic (or nationalistic) identity (Güvenç, 1997). Because of the millet system, the Ottomans regarded all Turkish speaking subjects as Muslims (Güvenç, 1997). This approach of the Empire was overwhelmingly accepted even by the Turks. The nationalist writer Ziya Gökalp acknowledged in 1923 that even Turks in Anatolia, the putative heartland of Turkey, did not think of themselves as Turks (Roberts and Şahin, 2010: 516). This tendency can be explained with the religious affiliations which weakened the ethnic Turkish identity as a result of the Ottoman millet system. Thus, Islam was the essential component in determining the identity of Turks. According to Lewis, 'among the different peoples who embraced Islam none went farther in sinking their separate identity in the Islamic community than the Turks' (quoted in Segars, 2003: 83).

During the Ottoman era Turkish identity was ethnic in nature; however, this ethnicity merely distinguished the Turkish speaking people from the others. Therefore, as Lewis pointed out, Islam was the only common criterion that was embraced by Turks to identify themselves vis-à-vis other groups until the collapse of the Ottoman Empire. In the aftermath of the fall of the Ottoman, the idea of 'Turkism' ${ }^{1}$ which was seeking to organize a policy of Turkish nationalism based on ethnicity came to the fore.

\subsection{Kemalist modernization}

Mustafa Kemal Atatürk, the founder of the new Turkish republic, rejected the idea of a multinational empire, thus, aimed to produce a nation state which was filled with ethnically homogenous citizens who were moved away from their Ottoman and Muslim past. Ataturk believed that national progress would come by emulating, absorbing and reproducing 'European' cultural values and political institutions (Haynes, 2010: 314). In order to transform Turkey to a Western type country, his fundamental aim was to establish

1 Turkism, Ottomanism and Islamism were the three policies articulated by Yusuf Akcura in 1900 in order to unify the Empire's people under one entity. 
and protect secularism. Due to this reason, over the next nine decades, Turkey's political circumstances have consistently reflected two key aspects of elite preference for secularism, focused in: (1) a strongly secularising and centralising state and, (2) political domination by the armed forces (Haynes, 2010: 314). However, with the collapse of the communism and as a result strong revival of religion and rising Islamic mobilization throughout the world, Turkey has started facing with the Islamic tendency both in the social realm and the political arena. The success of Islamic parties has triggered a deep- rooted crisis between secularists and non- secularists. On the other hand, it should be noted here that, despite social and political polarization and strong secularization, Islam still retains a strong social (and, to a degree, political) position in Turkey (Haynes, 2010: 313), which demonstrates that strong secularisation did not help to suppress religion among Turks.

As a result, in both periods of westernization of the Turks the decision to move towards Europe did not happen as a result of a slow social and cultural process, but, basically, it was enforced to the Turks from "above", either from the Sultan, or from Kemal Ataturk. This resulted to the fact that the idea of moving towards the West is not encompassed and embraced by the whole Turkish society. Towards this end, Huntington (2002) states that Turkey is a torn country because of its split character: some of the Turks look towards Europe and some towards Islam. The situation now is even more confusing since due to the negative opinion of the Europeans, Turkey moves to another level of 'torness' as modern Turks are not sure both about their decision to become like the West and be part of Europe as well as who they are; their national identity.

\section{The Major Factors Underlying the Negative Image of Turks}

In this section I will attempt to find out the factors that shaped the negative image of the Turks in Europe. I have identified three factors: the historical events that shaped the relations between Europe and Turkey/Ottoman Empire, the problematic social behaviour of the Turkish emigrants in Europe and the role of the woman in the Turkish society. In the following sub-sections I will present these factors in detail.

\subsection{Historical Background: The Ottoman's 'Otherness'}

According to Deringil, most of the negative imagery regarding Turkey in Europe can be dated back to the nationalist separatist struggles of the 19th century, starting with the Greek war of independence (1821-29) which was seen by the European romantics as a struggle between 'the descendants of Pericles' and the 'Turkish barbarians' (Deringil, 2007: 717). However, even before separatist struggles, Turks were associated with negative images by Europeans in order to define themselves in opposition to Muslim Ottoman. According to Bisaha, the association between 'Turks' and 'Barbarians' had become so strong by the second half of the 15th century that one often finds simple mentions of the 'barbarians' in state records, denoting Turks but without clarification of this fact.(Bisaha, 2004: 72). The expansionist and religiously different character of the Ottomans were overwhelmingly perceived as an 'enemy' who threatened the cultural and religious values of Europeans by expanding its psychical proximity to the 'Christendom'. However, at the same time this 
perceived character enforced the evaluation of the European identity. The 'Ottoman threat' raised the concerns among Europeans, which peaked with the fall of Constantinople, after which Pope Pius II called whole the Christianity to defend their religion against the Turks (quoted in Palabıyık, 2005: 41). In response to 'Turkish' threat, Christians produced a sense of solidarity which united them, in order to protect their religion which was synonymous with the protection of Europe for Christians.

However, with the reduction of the importance of religion in Europe after 16th century, 'Orientalist' discourse began to take precedence over religious criteria. Starting with the Protestant Reformation in the 16th century that marked the rise of Europe, Europe witnessed social, economic, intellectual and technological changes that carried Europe to the top vis-à-vis the 'Orient', which included the Ottomans. When the Ottoman Empire started to lose its power, inevitably, it turned its face towards Europe/West by importing science, technology, institutions, and ideas like nationalism and so on. Despite the fact that the Ottomans have entered a Westernization process and despite their active presence in the European system since the Concert of Europe, the negative image of Ottomans was maintained. Europeans continued to see Turkey as the 'other' with the late 18th century English parliamentarian and conservative thinker Edmund Burke declaring that the Turks were 'worse than savages' (Lovell, 2011: 174).

All these historical events that facilitated conflicts between Europe and Turkey are one of the main factors that shape the negative image of the Turks. In fact, even now where all these events belong to the past there is evidence that they are still contributing to the negative image of the Turks. For example, in the French social imaginary the connection of Turkey to the historical image of the Ottoman Empire is still alive (Tekin, 2008: 738). Similar to France, the historical image of Ottoman who besieged the Vienna twice is still alive in the minds of Austrians. According to Tomenendal, this negative historical image of Turks is still used by some political parties through slogans, such as 'Vienna cannot become an Istanbul' or 'Third siege of Vienna', in their electoral campaigns, especially after 2004, in order to maintain their power (Tomenendal, 2009: 373).

\subsection{Moving to Europe: Turkish Migrants in Europe}

At the beginning of 1960s, Turkey signed diplomatic agreements with Western European countries in order to compensate the work force deficit of Europe. Turkey signed Labour Force Agreements with various destination states beginning with Germany in 1961, followed by Austria, Belgium, Netherlands in 1964, France in 1965 and Australia in 1967 (Ministry of Foreign Affairs). Priority for emigration was given to applicants from less developed regions of Turkey, to members of Village Development Co-operatives, and to persons from officially designated disaster areas (Uçak, 2011: 191). Due to these reasons the workers (called 'guest workers') that were about to migrate to Europe had a very low literacy rate. For example, Teitelbaum and Martin write that Turks in Germany 'were the last guest workers to arrive in large numbers, the poorest, the least educated, and the most different cultural and historical terms' and they continued 'their integration was also impeded by sharp differences between Turkish and European cultural views on the roles of men and women, by the deep significance of Islam in the daily lives of many Turks.'(quoted in Tekin, 2005: 292). 
With the economic downfall of Europe in 1973 due to oil crisis, the emigration as a guest worker came to an end. The guest workers who initially were expected to return to their home countries, decided to stay, hence emigration continued through family reunification. All the guest worker programs focused on the fact that migrants were to leave on completion of their contracts (Cakirerk and West, 2009: 65). Therefore, the workers decision to stay was unexpected and this brought reluctance to accept them into the societies and a persisting denial of the reality that they were becoming permanent settlers. This collective denial of reality led to unsuccessful integration initiatives and in consequence to non-integrated migrant societies even now where the third generation is growing up in the host countries.

\section{Figure 1.Number of Turks in host European countries}

\begin{tabular}{|l|r|r|r|r|r|}
\hline Country & \multicolumn{1}{|c|}{$\mathbf{1 9 9 0}$} & \multicolumn{1}{c|}{$\mathbf{2 0 0 0}$} & \multicolumn{1}{c|}{$\mathbf{2 0 0 5}$} & \multicolumn{1}{c|}{$\mathbf{2 0 0 7}$} & \multicolumn{1}{c|}{$\mathbf{2 0 0 9}$} \\
\hline Germany & 83.6 & 1998.534 & 1764.041 & 1713.551 & 1658.083 \\
\hline France & & & & 223.425 & \\
\hline Belgium & 2.446 & 56.172 & 39.664 & 39.532 & \\
\hline Denmark & 1.069 & 35.232 & 29.491 & 28.843 & 28.972 \\
\hline Netherlands & 12.637 & 100.782 & 98.92 & 93.746 & 90.837 \\
\hline Switzerland & 6.038 & 79.5 & 75.448 & 72.633 & 71.039 \\
\hline Austria & & 127.3 & 115.5 & 109.179 & 112.15 \\
\hline
\end{tabular}

Source: OECD, http://stats.oecd.org/index.aspx, (data in thousands)

Besides the fact that most of the Turkish emigrants had low literacy rate the negative image was enhanced also by the fact that at the moment the Turkish migrant society seems to be more problematic than the other migrant societies. The Turkish- origin migrants have so far been overwhelmingly perceived by the autochthonous populations, as well as by the Turkish public as conservative, nationalist, religious and unwilling to integrate socially, politically, economically and culturally in their countries of settlement (Kaya, 2011: 499). As a result, it is often stated by various groups in Western European countries that negative perceptions of Turkey spring from those Turkish migrant workers who are not willing to comply with European norms and values (Kaya, 2011: 499). This leads to the situation where many of the members of the third generation of Turks in Europe do not even try to integrate to the society that they live. An example of the lack of integration effort is education.

Researches indicate that educational performance of Turkish background students in Europe is low in comparison to other students. Apart from the education level of the first generation, in the current generation school attendance, preschool attendance in particular, is very low. For instance, in 1989 in Germany, the percentage of attending to German schools was $39 \%$ among Turks in comparison to $80 \%$ among German kids, $75.5 \%$ among Portuguese kids and 68\% among Yugoslavian kids. (Suğanl, 2003: 21). An analysis of educational attainments on the second generation showed that Turkish children 
generally reaches lower level of education compare to others, therefore, school dropout rates and the educational achievements of these children stay lower. Therefore, they end up in special education classes, which were specially designed for children with learning disabilities (Avcı and Kirişci, 2006: 133). For example, in Germany almost a quarter of all Turkish students go to Hauptschule, the lowest track of secondary education (while only 13 percent of all West-German students do) (Avc1 and Kirişci, 2006: 133). Among the second-generation Turkish young people in France who have already ended their school careers, almost half have gained no secondary school diploma at all and the same situation repeated in Netherlands (one third got a diploma) and substantially fewer got one in Germany, Austria and Switzerland (Avcı and Kirişci, 2006: 133).

As a result, I can claim with certainty that educational levels and socio- economic status of Turks who initially migrated and settled and were born and lived in Europe play an important role in the construction of the negative images. Turks reluctance to go to school has generated problems that varied from lack of language skills to socializing problems with the rest of the society, ghettoization, and lack of vocational skills and so on. For these reasons we may find Turkish mothers who do not speak a word of German; Turkish girls who are not allowed to go to school or to attend certain classes, school sports and trips; and high violence and crime rates among male Turkish adolescents (Stelzenmüller, 2007: 109). For instance, according to a study in 1990 by Barbara John, the CDU spokeswoman for women in Berlin's regional government, Turkish women were still, even after so many years, 'completely alien to German society' and 'not capable of getting on without outside help' (Twigg and et al. 2005: 14). Low rates of participation in secondary education and vocational training have proven to be an additional barrier to adaptation and integration (Stelzenmüller, 2007: 109). Even though this fact has been changing recently thanks to the new generation who is more open than the previous ones, there are still problems occurring among Turks when especially compared to other national groups.

\subsection{The Role of Women in Turkish Society}

Similarly to the education problems, the disadvantaged role of women among Turks has a very significant impact on the perceived image of Turks. KONDA conducted a survey entitled 'Who Are We?' which was released in 2009 in Turkey. The poll found significant outcomes regarding the role of women in the society. According to poll's findings nearly half (49.9\% percent) of the Turks claimed that 'A women needs permission from her husband to be able to work'. Furthermore, more than half ( $57.1 \%$ percent) replied 'never' to the following statement 'Women in this household go out with sleeveless shirts.' Tarhan Erdem, headed the team that conducted the Konda survey, defined gender inequality as the key problem that could be linked to all other societal problems and he added 'The data shows that women are not free in their private lives'(Haynes, 2010: 321). Additionally, four out of 10 women in Turkey are beaten by their husbands, according to the recent study entitled "Domestic Violence against Women in Turkey," which has collected the first official statistics on this topic in Turkey (Sobecki, 2009). Even more disturbingly, the study reveals that a significant number of abused women, almost 90 percent, do not seek help from any organization (Sobecki, 2009). According to the report, 1091 honour crimes have been committed in Turkey between the years 2000 and 2005 (Livaneli, 2006) and 
there have been 45 honour killings by Turks on German soil since 1996 (Barysch, 2007: 4). Furthermore, a significant number of girls are exposed to forced marriages by their families, not only among Turks in Turkey, but also among Turkish immigrants. According to women organizations in Austria that are working with these topics the largest number of forced marriages take place among Turkish and Kurdish migrants (Koc, 2009: 112)

All these findings demonstrate that women have a 'second class' status in the Turkish society and men strongly dominate the relations with women. As a result, more than 90 percent of Germans now believe that Islam is hostile and aggressive to women, according to a survey cited by the European Stability Initiative (ESI),(Barysch, 2007: 4). For the Europeans Islam was the main reason for explaining why many Turks treat women in such way. If we combine this situation with the extremely negative image of Islam, which has risen after the September 11th New York attacks and doubled with the attacks in Madrid and London respectively, it is clear to understand why the Turks are considered as backward, socially problematic and conservative.

\section{Discussion}

In the previous sections I have presented the factors that shaped the negative image of the Europeans regarding the Turks. In this section I will discuss the effect of this image on the EU membership of Turkey.

In 2004, before the accession negotiations started between Turkey and the EU, Commission clearly stated that Turkey's accession will be different than the previous enlargements 'because of the combined impact of Turkey's population, size, geographical location, economic, security and military potential, as well as cultural and religious characteristics.' (Commission of the European communities, 2004c: 4). Indeed, Turkey's accession process stimulated a fierce debate among the public, politicians and academia.

According to Eurobarometer surveys, the support for Turkey's accession from the European public stays around 30\% percent, which is the lowest degree in relation to other candidate countries. In an internet poll conducted by the Turkish Embassy in Vienna, 74\% of the participants declared that Turkey was not a European country. 40\% claimed they would disapprove of Turkish membership even if the country fulfilled all the necessary conditions and no labour migration would take place. $20 \%$ stated that Turkey must never be allowed into the Union (Günay, 2007: 52). Furthermore, in a research conducted by Y1lmaz in 2009 in key EU member countries regarding the public's opinion against Turkish full membership, 39 percent stated that Turkey is a Muslim country and not compatible with the common Christian roots, hence religion accounts for the most important argument in the poll (Saz, 2011: 483). However, when Europeans are asked about the values that matter most to them, religion seems the least important one. According to Eurobarometer survey which released 2011, when they were asked to name the values which matter most to them, Europeans place human rights first $(47 \%,+7$ compared with EB 72 , in autumn $2009)$, followed by peace $(44 \%,+2)$, respect for human life $(41 \%,-3)$, democracy $(29 \%$, $+5)$, individual freedom $(23 \%,-1)$, the rule of law $(22 \%,+2)$, equality $(19 \%,+1)$, solidarity $(15 \%,-2)$, tolerance $(15 \%,-4)$, self-fulfilment $(10 \%,-3)$, respect for other cultures $(8 \%$, unchanged) and religion (6\%, unchanged) (Eurobarometer 74$)$. 


\section{Support for Turkey's Membership in the European public}

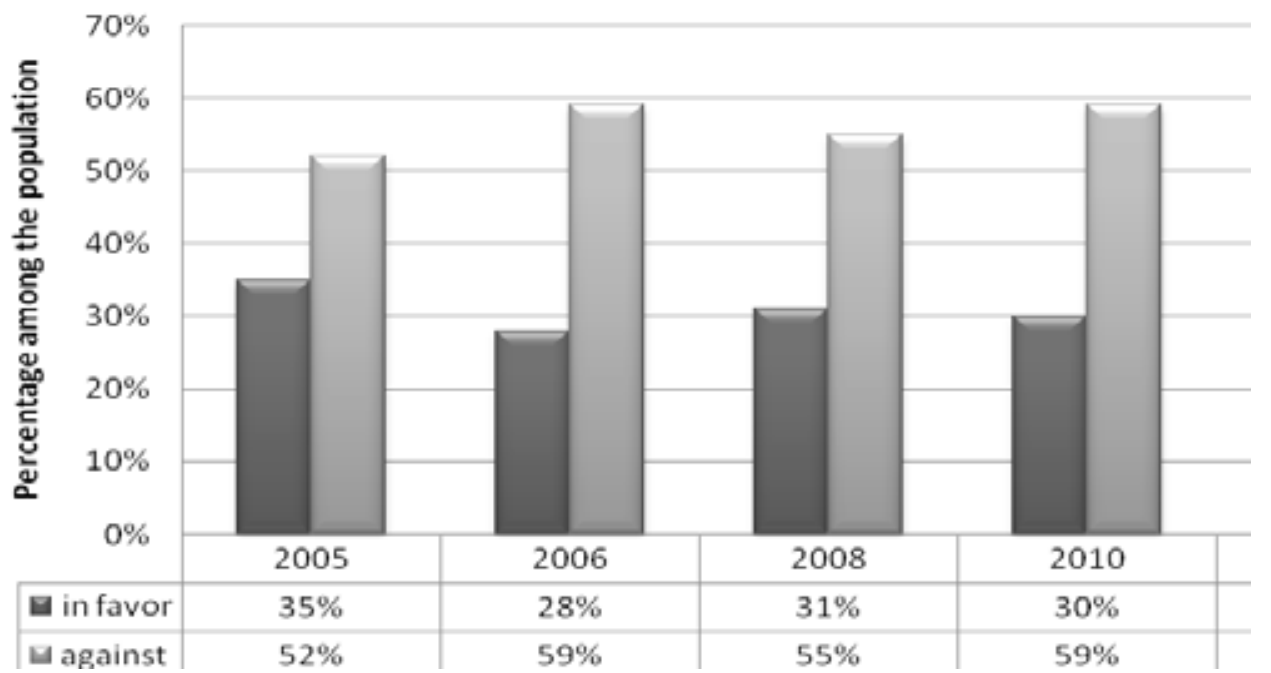

Figure 2. The public opinion against Turkey's membership in the member countries according to Eurobarometer surveys that conduct by European Commission.

Similar to public stance on Turkey's accession, politicians express their opinion more loudly on the grounds that Turkey is too 'different'. Debate among politicians has started with Valery Giscard d'Estaing's famous statement which was clearly putting Turkey out of the Europe map. D'Estaing stated in 2002 that 'Its capital is not in Europe; 95 percent of its population live outside Europe; it is not a European country...In my opinion, it would be the end of Europe' (Sciolino, 2002). Like d'Estaing, Nicolas Sarkozy and Angela Merkel discussed Turkey's membership on the cultural and religious ground, and instead of a full membership they offered 'partnership' which provides a full economic integration while restricting political rights of Turkey in the Union. Nicolas Sarkozy evaluated Turkey's membership with the following statement: 'I do not believe that Turkey belongs in Europe, and for one simple reason: because it is Asia Minor. What I wish to offer Turkey is a true partnership with Europe, but not integration into Europe' (Steunenberg et al., 2011). Angela Merkel, like Nicolas Sarkozy, offered 'privileged partnership' which does not include a full membership. Yet for the Turkish decision makers a full membership is seen as the only way in the relations with Europe. From the view point of the European public and the politicians Turkey is culturally too different and these differences cannot allow this 'marriage'.

On one hand there is 'split' character of Turks, which polarizes the Turkish society as secularists and non- secularists while 83 percent of Turks identify themselves as religious according to International Social Survey Program that measures religious values (Religion loves tolerance, but it is not tolerant, Hürriyet, 2009). On the other hand, as shown before, there are several combined factors that constantly enhance the negative image of the Turks and that has a tremendous effect on Turkey's EU membership. These factors demonstrate that socio- cultural differences create a great gap, therefore some countries - France and Austria- have already announced that they will hold a referendum in the last phase. 


\section{Conclusion}

This paper shows that increasing difficulties of being supported by European public is a result of direct interaction between Turks and Europeans, which has mostly generated negative feelings about the 'other'. The factors that are given above, shaped the Turkish perception in a negative way, and they constitute the essence of the problem. It is certainly true that Turkey has affirmed its commitment to setting a pace on modernization in European standards, which in turn has resulted in a period of number of enormous changes, which make the Turkish society more open, modern and moderate. However, it can be observed that Turkey is not united in itself. The division between modern, secular and westernoriented part and conservative, more religious and more 'close' part of Turkey creates doubts among Europeans. Additionally, the presence of Turkish migrant community in Europe is seen as a representative of all Turks, thus, collective negative belief has emerged among Europeans by linking migrants attitudes to Turks in general, which in turn makes positive examples less prominent. As shown above, the approach of Turks to wide range problems including human rights, equality between genders, persisting educational failure, which are core elements for European value system, create great differences between Europe and Turkey. And it seems as long as these factors continue, the support for Turkey will remain low. 


\section{REFERENCES}

- AKÇURA, Y. (2011). Üç Tarz-1 Siyaset (Three Policies). Ankara: Kilit Yayınları.

- AVCI, G. and Kirisci, K. (2006). 'Turkey's Immigration and Emigration Dilemmas At the Gate of the European Union'. Conference on Migration and Development Challenges: Perspectives from the South 10-13 July 2006. Italy: Bellagio.

- BARYSCH, K. (2007). 'What Europeans Think about Turkey and Why', Centre for European Reform, http://www.cer.org.uk/publications/archive/essay/2007/what-europeans-think-aboutturkey-and-why. 10.01.2012

- BISAHA, N. (2004). Creating East and West, Renaissance Humanists and the Ottoman Turks, Philadelphia: University of Pennsylvania Press.

- CAKIRERK, R. and West, J. (2009). The socio- Economic Position of the Turkish Community in Belgium: The Challenge of Integration Talip Kucukcan and Veyis Gungor (ed.). Turks in Europe Culture, Identity, Integration inside, (p.65-78). Turkevi Research Centre.

- DERINGIL, S. (2007). 'The Turks and 'Europe': The Argument from History', Middle Eastern Studies, Vol.43, No.5, 709-723.

- GÜNAY, C. (2007). Conditionality, Impact and Prejudice in EU- Turkey Relations: A View from Austria, Nathalie Tocci (ed.). Conditionality, Impact and Prejudice in EU- Turkey Relations inside, (p.46-57). IAI- TEPAV Report

- GUVENC, B. (1997). 'Secular Trends and Turkish Identity', (Online Version). Journal of International Affairs, Vol.2, No.4.

- HAYNES, J. (2010). 'Politics, Identity and Religious Nationalism in Turkey: From Atatürk to the AKP', Australian Journal of International Affairs, Vol.64, No.3, 312-327.

- HUNTINGTON, S. P. (2002). The Clash of Civilizations And The Remaking of World Order, UK: The Free Press.

- INAC, H. (2004). 'Identity Problems of Turkey during the European Union Integration Process', Journal of Economic and Social Research, 6 (2), 33-62.

- KAYA, A. (2011). 'Euro- Turks as a Force in EU- Turkey Relations', South European Society and Politics, Vol.16, No.3, 499-512.

- KOC, G. (2009), Turks in Austria and Germany: Stereotypes and Xenophobia Talip Kucukcan and Veyis Gungor (ed.). Turks in Europe Culture, Identity, Integration inside, (p. 103-127). Turkevi Research Center.

- KONDA Public Poll (http://www.konda.com.tr/en/). 
- LIVANELİ, Z. (2006). Honor Killings and Violence against Women in Turkey, Turkish Cultural Foundation. $\quad$ http://www.turkishculture.org/lifestyles/turkish-culture-portal/thewomen/honorkillings-426.htm, 25.04.2012.

- LOVELL, D. (2011). 'Turkey in Europe: Record, Challenges and the Future', Insight Turkey, Vol.13, No.3, 173-190.

- MÜFTÜLER- BAC, M. (2000). 'Through the Looking Glass: Turkey in Europe', Turkish Studies, Vol.1, No.1, 21-35.

- OECD Statistics (http://stats.oecd.org/index.aspx).

- PALABIYIK, M. S. (2005). Contributions of the Ottoman Empire to the Construction of Modern Europe, Yayınlanmamış Master Tezi, Middle East Technical University, Ankara, Turkey.

- Republic of Turkey Ministry of Foreign Affairs (http://www.mfa.gov.tr/the-expatriate-turkishcitizens.en.mfa).

- 'Religion loves tolerance... ‘(2009, 17 November). Hürriyet Daily News.

- ROBERTS, T. and Şahin, M. (2010). 'Construction of National Identities in Early Republics: A Comparison of the American and Turkish Cases', The Journal of the Historical Society, Vol.10, Issue 4, 507-531.

- SAZ, G. (2011). 'Turkophobia and Rising Islamophobia in Europe: A Quantification For the Negative Spillovers on the EU Membership Quest of Turkey', European Journal of Social Sciences, Vol.19, No.4, 479-491.

- SCIOLINO, E. (2002, 9 November). 'Ex- French President Snubs...' The New York Times.

- SEGARS, A. (2003). Nation Building in Turkey and Uzbekistan: the use of language and history in the creation of national identity, Tom Everett- Heath (ed.). Central Asia: Aspects of Transition inside, (p.80-106). London: Routledge-Curzon Publication.

- SOBECKI, N. (2010, 20 February). 'Turkey’s Shocking Domestic... ' GlobalPost.

- STELZENMULLER, C. (2007). Turkey's EU Bid: A View from Germany Nathalie Tocci (ed.). Conditionality, Impact and Prejudice in EU-Turkey Relations inside, (p. 106-118). IAI-TEPAV Report.

- STEUNENBERG, B. et al. (2011). 'Between Reason and Emotion: Popular Discourses on Turkey's Membership of the EU', South European Society and Politics, Vol.16, No.3, 449-468.

- SUĞANLI, M. (2003). Almanya'da Yaşayan ve Türkiye Cumhuriyeti Merkez Bankası'nda Hesabı Bulunan Türklerin Sosyo- Ekonomik Yapısı ve Isş̧̧i Dövizleri. Uzmanlık Yeterlilik Tezi. Türkiye Cumhuriyet Merkez Bankası İşçi Dövizleri Genel Müdürlüğü, Ankara, Turkey.

- TEKIN, B. Ç. (2008). 'The Construction of Turkey's Possible EU Membership in French French Political Discourse', Discourse Society, Vol.19 (6), 727-763. 
- TEKİN, A. (2005). 'Future of Turkey- EU Relations: A Civilisational Discourse', Futures, Vol.37, Issue. 4, 287-302.

- TOMENENDAL, K. (2009). ‘Öteki’ Olarak Kimlik ya da Batı Gözüyle Türk İmgesi Gönül Pultar (ed.). Kimlikler Lütfen Türkiye Cumhuriyeti’nde Kültürel Kimlik Arayışı ve Temsili inside, (p.373383). Ankara: ODTÜ Publications.

- TWIGG, S. et al. (2005). 'Turks in Europe: Why Are We Afraid?’ UK: Foreign Policy Centre.

- UÇAK, H. (2011). 'Turkey's Population Dynamics as a Candidate Country for EU Membership', International Journal of Economics and Financial Issues, Vol.1, No.4, 180-198.

- VERNEY, S. (2007). 'National Identity and Political Change on Turkey's road to EU membership', Journal of Southern Europe and the Balkans Online, Vol.9, No.3, 213-221. 
